\title{
TP53 gene deletion in esophageal cancer tissues of patients and its clinical significance
}

\author{
MADINIYET NIYAZ ${ }^{1}$, ABDUGHENI TURGHUN ${ }^{2}$, ZHANG HAI PING ${ }^{2}$, \\ ZHANG ZHU $^{2}$, ILYAR SHEYHEDIN ${ }^{2}$, CAI REN ${ }^{1}$ and IDIRIS AWUT ${ }^{2}$ \\ ${ }^{1}$ Xinjiang Esophageal Cancer Research Institute, Medical Research Center, ${ }^{2}$ Department of Thoracic Surgery, \\ First Affiliated Hospital, Xinjiang Medical University, Urumqi, Xinjiang 830054, P.R. China
}

Received May 15, 2012; Accepted September 12, 2012

DOI: $10.3892 / \mathrm{mmr} .2012 .1162$

\begin{abstract}
The aim of this study was to examine TP53 gene deletion in esophageal cancer (EC) tissues obtained from patients and to evaluate its clinical significance. Forty surgical specimens from patients with esophageal squamous cell carcinoma were examined for TP53 gene deletion using the fluorescence in situ hybridization (FISH) technique. Thirty-two male and 8 female patients were enrolled, with an average age of 56 years. TP53 gene deletion was significantly higher in poorly-differentiated EC cases compared to welldifferentiated cases $(\mathrm{P}=0.028)$. The TP53 gene deletion rate was also significantly higher in the group with lymph node metastasis compared to the group without lymph node metastasis $(\mathrm{P}=0.0313)$. The TP53 gene deletion rate was shown to be correlated with the level of differentiation and lymph node metastasis in EC; it may therefore be an important molecular marker for evaluating the condition of EC in patients.
\end{abstract}

\section{Introduction}

Esophageal cancer (EC) is one of the most common gastrointestinal cancers in the world and there is a clear regional and ethnic difference in terms of its incidence rate and etiology factors (1). The incidence of EC has been as high as 68.88/100,000 among the Kazakhs living in the Xinjiang Uyghur Autonomous Region (Northwest region of China). In China, the histopathological type of EC is different from that found in Europe and America and majority of cases are

Correspondence to: Dr Idiris Awut, Department of Thoracic Surgery, First Affiliated Hospital, Xinjiang Medical University, 137 Liyushan South Road, Urumqi, Xinjiang 830054, P.R. China E-mail: edrs5@yahoo.com

Abbreviations: FISH, fluorescence in situ hybridization; EC, esophageal cancer; CEP17, centromere of chromosome 17; SSC, standard saline citrate

Key words: TP53 gene, Kazakh, esophageal squamous cell carcinoma, FISH squamous cell carcinomas. EC is related to the activation of multiple genes and is a multi-step process. Oncogene activation and tumor suppressor gene inactivation are the basis for the development of molecular genetics. Currently, the p53 gene is the most important tumor suppressor gene and is located on human chromosome $17 \mathrm{p} 13.1$, which regulates the cell cycle and induces cell apoptosis $(2,3)$.

Fluorescence in situ hybridization (FISH) is a cytogenetic technique that has gradually developed in recent years, involving the use of fluorescent labeled DNA probes to detect cell changes within the chromosome (4). Several studies have demonstrated that p53 gene deletion is important in the development and progression of EC (5-7). However, reports on the p53 gene deletion associated with Xinjiang Kazakh EC patients are absent.

In this study, we used FISH to detect TP53 gene deletion in 40 esophageal carcinoma cases in Kazakh patients, in order to analyze its clinical significance in evaluating patients' prognosis based on molecular pathology.

\section{Patients and methods}

From October 2010 to December 2011, 40 Kazakh EC patients were admitted to the Department of Thoracic Surgery, First Affiliated Hospital of Xinjiang Medical University, and underwent surgical resection. There were 32 male and 8 female patients, with an average age of 56 years (ranging from 31 to 82 ). None of the patients had received any preoperative radiotherapy, chemotherapy or other special treatment.

Pathological diagnosis confirmed esophageal squamous cell carcinoma in 40 cases post-operatively, including well-differentiated tumors in 14 cases, moderately differentiated tumors in 12 cases and poorly differentiated tumors in 14 cases (Table I). Ten samples of normal esophageal tissues ( $>5 \mathrm{~cm}$ from the tumor) were collected as normal controls. Informed consent was obtained from all patients.

Touch preparations of cells were made on glass slides from fresh specimens and air-dried overnight at room temperature and then stored at $-80^{\circ} \mathrm{C}$ ready for FISH. The same specimens were stained with hematoxylin and eosin (H\&E) for pathological evaluation. FISH detection was followed by Nakamura's improved Vysis protocol (8). Direct fluorochrome-labeled centromeric probes were used for enumeration of different 
Table I. Results of p53 and CEP17 by FISH.

\begin{tabular}{|c|c|c|c|c|c|c|c|c|}
\hline \multirow[b]{2}{*}{ Case } & \multirow[b]{2}{*}{ Age (years) } & \multirow[b]{2}{*}{ Gender } & \multicolumn{5}{|c|}{ Copy no. } & \multirow[b]{2}{*}{ FISH } \\
\hline & & & $\begin{array}{c}0 \\
\text { p53/CEP17 }\end{array}$ & $\begin{array}{c}1 \\
\mathrm{p} 53 / \mathrm{CEP} 17\end{array}$ & $\begin{array}{c}2 \\
\mathrm{p} 53 / \mathrm{CEP} 17\end{array}$ & $\begin{array}{c}3 \\
\mathrm{p} 53 / \mathrm{CEP} 17\end{array}$ & $\begin{array}{c}4 \\
\text { p53/CEP17 }\end{array}$ & \\
\hline 1 & 53 & M & $3 / 0$ & $35 / 0$ & $60 / 26$ & $2 / 34$ & $0 / 40$ & Deletion \\
\hline 2 & 65 & M & $4 / 0$ & $33 / 0$ & $40 / 30$ & $15 / 45$ & $8 / 25$ & Deletion \\
\hline 3 & 45 & M & $5 / 0$ & $23 / 0$ & $58 / 54$ & $13 / 28$ & $1 / 18$ & Normal \\
\hline 4 & 54 & $\mathrm{~F}$ & $1 / 0$ & $21 / 0$ & $51 / 62$ & $21 / 30$ & $6 / 8$ & Normal \\
\hline 5 & 50 & $\mathrm{M}$ & $3 / 0$ & $35 / 0$ & $56 / 79$ & $4 / 11$ & $2 / 10$ & Deletion \\
\hline 6 & 51 & $\mathrm{~F}$ & $0 / 0$ & $25 / 0$ & $74 / 77$ & $1 / 12$ & $0 / 11$ & Normal \\
\hline 7 & 41 & $\mathrm{M}$ & $4 / 0$ & $21 / 0$ & $69 / 72$ & $5 / 15$ & $1 / 13$ & Normal \\
\hline 8 & 63 & $\mathrm{M}$ & $5 / 0$ & $11 / 0$ & $84 / 68$ & $0 / 18$ & $0 / 14$ & Normal \\
\hline 9 & 46 & $\mathrm{M}$ & $0 / 0$ & $18 / 0$ & $76 / 71$ & $6 / 21$ & $0 / 8$ & Normal \\
\hline 10 & 56 & M & $9 / 0$ & $36 / 0$ & $53 / 46$ & $2 / 39$ & $0 / 15$ & Deletion \\
\hline 11 & 68 & M & $10 / 0$ & $40 / 0$ & $49 / 67$ & $1 / 19$ & $0 / 14$ & Deletion \\
\hline 12 & 63 & $\mathrm{M}$ & $14 / 0$ & $44 / 0$ & $33 / 51$ & $9 / 41$ & $0 / 8$ & Deletion \\
\hline 13 & 66 & M & $4 / 0$ & $10 / 0$ & $63 / 48$ & $16 / 21$ & $7 / 8$ & Normal \\
\hline 14 & 71 & M & $5 / 0$ & $42 / 1$ & $50 / 48$ & $3 / 36$ & $0 / 15$ & Deletion \\
\hline 15 & 44 & M & $3 / 0$ & $30 / 0$ & $60 / 69$ & $4 / 29$ & $3 / 2$ & Deletion \\
\hline 16 & 63 & M & $5 / 0$ & $40 / 0$ & $49 / 51$ & $6 / 28$ & $0 / 21$ & Deletion \\
\hline 17 & 71 & $\mathrm{M}$ & $7 / 0$ & $44 / 0$ & $48 / 68$ & $1 / 20$ & $0 / 12$ & Deletion \\
\hline 18 & 52 & $\mathrm{M}$ & $10 / 0$ & $31 / 0$ & $41 / 52$ & $13 / 15$ & $5 / 33$ & Deletion \\
\hline 19 & 45 & $\mathrm{M}$ & $11 / 0$ & $45 / 0$ & $39 / 61$ & $5 / 30$ & $0 / 9$ & Deletion \\
\hline 20 & 70 & $\mathrm{M}$ & $0 / 0$ & $19 / 0$ & $58 / 66$ & $14 / 31$ & $9 / 3$ & Normal \\
\hline 21 & 52 & $\mathrm{~F}$ & $3 / 0$ & $25 / 0$ & $45 / 59$ & $20 / 28$ & $7 / 13$ & Normal \\
\hline 22 & 37 & $\mathrm{~F}$ & $2 / 0$ & $24 / 0$ & $69 / 60$ & $4 / 24$ & $1 / 16$ & Normal \\
\hline 23 & 56 & M & $5 / 0$ & $36 / 0$ & $41 / 50$ & $16 / 34$ & $2 / 16$ & Deletion \\
\hline 24 & 56 & M & $2 / 0$ & $39 / 0$ & $54 / 60$ & $3 / 21$ & $2 / 19$ & Deletion \\
\hline 25 & 60 & $\mathrm{~F}$ & $2 / 0$ & $38 / 0$ & $35 / 46$ & $25 / 39$ & $0 / 15$ & Deletion \\
\hline 26 & 64 & $\mathrm{~F}$ & $3 / 0$ & $40 / 0$ & $42 / 41$ & $15 / 53$ & $0 / 6$ & Deletion \\
\hline 27 & 54 & $\mathrm{~F}$ & $4 / 0$ & $41 / 0$ & $33 / 52$ & $22 / 20$ & $0 / 28$ & Deletion \\
\hline 28 & 66 & M & $4 / 0$ & $35 / 0$ & $41 / 56$ & $20 / 30$ & $0 / 14$ & Deletion \\
\hline 29 & 51 & M & $3 / 0$ & $30 / 0$ & $50 / 67$ & $10 / 23$ & $7 / 10$ & Deletion \\
\hline 30 & 45 & M & $5 / 0$ & $23 / 0$ & $58 / 49$ & $13 / 30$ & $1 / 21$ & Normal \\
\hline 31 & 58 & $\mathrm{M}$ & $3 / 0$ & $44 / 1$ & $50 / 45$ & $2 / 41$ & $1 / 13$ & Deletion \\
\hline 32 & 70 & $\mathrm{M}$ & $0 / 0$ & $40 / 0$ & $55 / 42$ & $5 / 36$ & $0 / 22$ & Deletion \\
\hline 33 & 64 & $\mathrm{~F}$ & $4 / 0$ & $20 / 0$ & $63 / 49$ & $12 / 32$ & $1 / 19$ & Normal \\
\hline 34 & 50 & M & $1 / 0$ & $28 / 0$ & $47 / 50$ & $22 / 34$ & $2 / 16$ & Normal \\
\hline 35 & 62 & M & $0 / 0$ & $25 / 0$ & $68 / 70$ & $6 / 17$ & $1 / 13$ & Normal \\
\hline 36 & 52 & M & $3 / 0$ & $33 / 0$ & $58 / 62$ & $6 / 36$ & $0 / 2$ & Deletion \\
\hline 37 & 50 & M & $3 / 0$ & $21 / 0$ & $70 / 70$ & $6 / 22$ & $0 / 8$ & Normal \\
\hline 38 & 48 & M & $4 / 0$ & $19 / 0$ & $58 / 51$ & $15 / 39$ & $4 / 10$ & Normal \\
\hline 39 & 60 & M & $5 / 0$ & $21 / 0$ & $74 / 60$ & $0 / 26$ & $0 / 14$ & Normal \\
\hline 40 & 60 & $\mathrm{M}$ & $3 / 0$ & $20 / 0$ & $57 / 50$ & $20 / 37$ & $0 / 13$ & Normal \\
\hline
\end{tabular}

CEP17, centromere of chromosome 17; FISH, fluorescence in situ hybridization.

chromosomes. Spectrum orange-labeled and spectrum greenlabeled probes for the TP53 and centromere of chromosome 17 (CEP17) were purchased from the manufacturer (Vysis, Inc., Downers Grove, IL, USA).
Cells were denatured with $70 \%$ formamide and then washed twice in standard saline citrate (SSC) at $74^{\circ} \mathrm{C}$ and at room temperature, respectively, for $2 \mathrm{~min}$ in a water bath. The slides were then dehydrated through a graded ethanol series $(70,85$ 

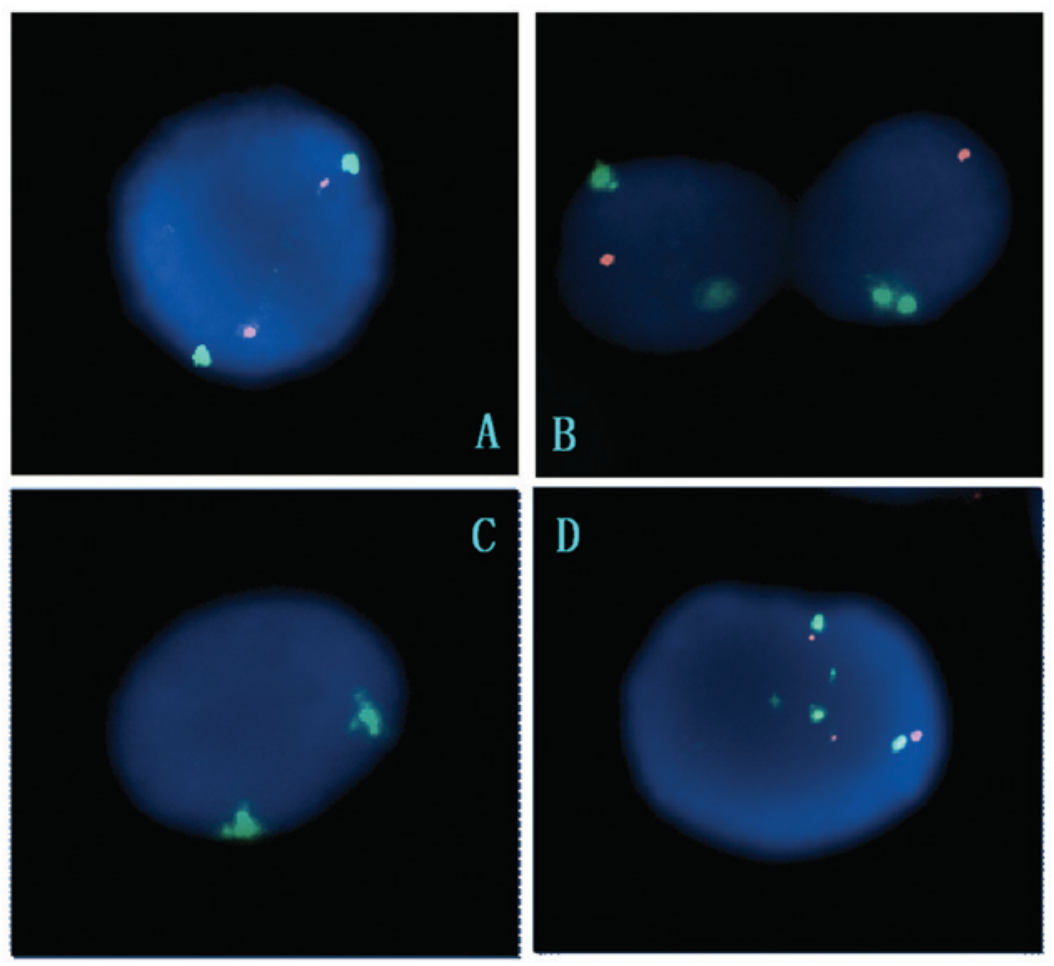

Figure 1. FISH analysis of TP53 (orange signals) and CEP17 (green signals). (A) Normal representative nuclei carrying 2 copies of TP53 and CEP17. (B) Partial deletion; nuclei carrying 1 copy of TP53 and 2 copies of CEP17. (C) Complete deletion; nuclei carrying 0 copy of TP53 and 2 copies of CEP17. (D) Amplification, nuclei carrying 3 orange signals and 5 green signals. FISH, fluorescence in situ hybridization. CEP17, centromere of chromosome 17.

and $100 \%$, each for $2 \mathrm{~min}$ ). We then applied $10 \mu \mathrm{l}$ of hybridization solution containing $1 \mu \mathrm{l}$ of each of the DNA probes, $7 \mu \mathrm{l}$ of hybridization buffer and $1 \mu 1$ of double distilled water. This was covered with a cover slip and sealed with rubber cement. Following incubation for $16 \mathrm{~h}$ at $42^{\circ} \mathrm{C}$ in a humidity-controlled chamber, the slides were washed with an SSC solution for $5 \mathrm{~min}$ at $74^{\circ} \mathrm{C}$ and at room temperature for $2 \mathrm{~min}$. Then $5 \mu \mathrm{l}$ diamidinophenylindole (DAPI, II) was applied to each spot and covered with a cover slip. The slides were observed under a fluorescence microscope that was connected to a cooled charge-coupled device camera. According to the kit instructions, under a fluorescence microscope, a special image acquisition and analysis system (Leica Microsystems, Ltd., Germany) was used for the signal count. In total, 100 nuclei were observed to obtain the number of p53 gene signals, such as 1 or 0 ; when nucleus fluorescence was $>30 \%$, we determined p53 gene deletion.

Microsoft Social Sciences 15.0 software (SPSS software, Chicago, IL, USA) was used for statistical analysis. The corrected $\chi^{2}$ test or the Scheffe method were used for univariate analysis of data from each group. $\mathrm{P}<0.05$ was considered to indicate a statistically significant difference.

\section{Results}

Orange (TP53) and green (CEP17) fluorescence signals were detected in all EC specimens. CEP17 hybridization signals were larger and brighter than TP53 gene signals. The representative FISH models included: normal, 2 intranuclear orange signals and 2 intranuclear green signals; partial deletion, $\geq 2$ intranuclear green signals and 1 intranuclear orange signal; complete deletion, $\geq 2$ intranuclear green signals and 0 orange signals (Fig. 1). Table I shows the TP53 gene deletion in the 40 esophageal carcinoma cases.

Table II shows the correlation between clinicopathological factors and TP53 deletion. Statistical analysis indicated that there were no significant correlations among TP53 gene deletion rate, age and gender $(\mathrm{P}>0.05)$. TP53 gene deletion rates were $28 \%(4 / 14)$ and $78 \%(11 / 14)$ in well-differentiated and poorly-differentiated $\mathrm{EC}$, respectively $(\mathrm{P}=0.028)$. TP53 gene deletion rates were $38 \%(7 / 18)$ and $72 \%(16 / 22)$ in the lymph node metastasis and no lymph node metastasis groups, respectively $(\mathrm{P}=0.0313)$. A high frequency of CEP17 hyperdisomy was detected.

\section{Discussion}

The causes of EC are complicated. At present, EC is considered as a multi-factor, polygenic variant, multi-staged disease. The variation of correlated proto-oncogenes and tumor suppressor genes is the key to tumorigenesis and development. Deletion of the tumor suppressor gene is the major mode of variation (9).

The p53 gene is currently thought to be the most important tumor suppressor gene and more than $50 \%$ of tumors are associated with its abnormality. p53 genetic mutation is important in the development of EC. Studies have indicated that patients with p53 genetic mutation had poorer prognosis and greater malignancy $(10,11)$. Multiple studies have proven that p53 genetic mutation is an independent and reliable biological parameter for evaluating the disease prognosis $(12,13)$. Due to p53 gene deletion or abnormality, cells with injured DNA enter into S stage, resulting in changes to heredi- 
Table II. Correlation between p53 gene deletion and clinicopathological factors.

\begin{tabular}{lrrr}
\hline $\begin{array}{l}\text { Clinicopathological } \\
\text { parameters }\end{array}$ & Case & $\begin{array}{c}\text { p53 } \\
\text { deletion }\end{array}$ & P-value \\
\hline Age (years) & & & \\
$\quad<50$ & 11 & 3 & 0.0695 \\
$\geq 50$ & 29 & 19 & \\
Gender & 32 & 19 & 0.4745 \\
$\quad$ Male & 8 & 3 & \\
Female & & & \\
Differentiation & 14 & 4 & 0.028 \\
$\quad$ Well-differentiated & 12 & 7 & \\
$\quad$ Moderately differentiated & 14 & 11 & \\
$\quad$ Poorly differentiated & & & \\
Lymph node metastasis & 18 & 7 & 0.0313 \\
$\quad$ No metastasis & 22 & 16 & \\
$\quad$ Metastasis & & & \\
\hline
\end{tabular}

tary characteristics, chromosomal aberration and, ultimately, carcinomatous change.

FISH is a technique using fluorescently labeled single-chain nucleotide DNA probes, based on the base complementarity principle, to form double-stranded nucleic acid with complementary single chain nucleotides by specific binding, and to detect cell chromosome changes and definite gene copy number changes in order to diagnose malignant cells. FISH is capable of detecting all types of cytogenetic changes, including aneusomy, amplification and deletion. Recently, FISH has been used in the diagnosis of hematologic malignancy, lung, breast and renal cancer, and it is a technique with high sensitivity and specificity (4,14-17).

In the past, there were limitations in the detection of mutant p53 protein by immunohistochemical methods since viral infection and stress may also produce p53 protein aggregation, and therefore samples may have contained both mutant and wild-type variants. Several studies found that the p53 protein positive rate was lower than that observed using PCR-SSCP detection, which indicates that p53 mutation or abnormality in the malignant tumor is much higher than that shown by immunohistochemisty detection in real situations (18). The sensitivity of FISH is similar to isotope hybridization in situ, but the space resolution and gene mapping accuracy is higher; therefore, FISH plays a significant role in tumor studies $(8,18,19)$.

In this study, FISH was applied using double-color DNA probes (fluorescent orange-labeled LSI TP53 probe and fluorescent green-labeled CEP17 probe) to detect TP53 gene deletion in Kazakh esophageal squamous cell cancer patients (7,20).

In the normal controls, in over $90 \%$ of nuclei, CEP17 and TP53 genes displayed 2 signals, indicating that FISH was successful in our study (data not shown). Among $40 \mathrm{EC}$ cases, the mean TP53 gene deletion rate was 55\% (22/40), and $28 \%(4 / 14), 58 \%(7 / 12)$ and $78 \%(11 / 14)$ in well-differentiated, moderately differentiated and poorly differentiated cases, respectively. This indicates that the TP53 gene deletion rate is correlated with the level of differentiation; the higher the differentiation, the higher the TP53 deletion rate. Moreover, the TP53 gene deletion rate also correlated with lymph node metastasis $(\mathrm{P}=0.0313)$. Similar studies support our results $(21,22)$.

Our study used FISH to detect the TP53 gene in Kazakh patients with EC, and the results show for the first time that the TP53 gene deletion rate is correlated with the level of differentiation and lymph node metastasis in ECs, and may be an important molecular biological marker for evaluating the condition of ECs in Kazakh patients. Further study on the post-operative life span of these patients is required to confirm the correlation of TP53 gene deletion and EC prognosis.

\section{Acknowledgements}

This study was funded by the Xinjiang Uyghur Autonomous Region Key Discipline and Specialties Foundation (2010-09), and the First Affiliated Hospital of Xinjiang Medical Univeristy Research Award Foundation (2012-YFY-27). Special thanks to the Department of Hematology of the First Affiliated Hospital of Xinjiang Medical University for technical support.

\section{References}

1. Lu XM, Zhang YM, Lin RY, Arzi G, Wang X, Zhang YL, Zhang Y, Wang Y, and Wen H: Relationship between genetic polymorphisms of metabolizing enzymes CYP2E1, GSTM1 and Kazakh's esophageal squamous cell cancer in Xinjiang. World J Gastroenterol 11: 3651-3654, 2005.

2. Schmale $\mathrm{H}$ and Bamberger $\mathrm{C}$ : A novel protein with strong homology to the tumor suppressor p53. Oncogene 15: 1363-1367, 1997.

3. Graesslin O, Chantot-Bastaraud S, Lorenzato M, Birembaut P, Quéreux C and Daraï E: Fluorescence in situ hybridization and immunohistochemical analysis of p53 expression in endometrial cancer: prognostic value and relation to ploidy. Ann Surg Oncol 15: 484-492, 2008.

4. Halling KC and Kipp BR: Fluorescence in situ hybridization in diagnostic cytology. Hum Pathol 38: 1137-1144, 2007.

5. Li WJ and Duan JX: Detecting of p53 gene heterozygosity loss in esophageal carcinoma tissues. JZU Med Sci 39: 499-501, 2004.

6. Hollstein MC, Metcalf RA, Welsh JA, Montesano R and Harris CC: Frequent mutation of the p53 gene in human esophageal cancer. Proc Natl Acad Sci USA 87: 9958-9961, 1990.

7. Audrézet MP, Robaszkiewicz M, Mercier B, et al: TP53 gene mutation profile in esophageal squamous cell carcinomas. Cancer Res 53: 5745-5749, 1993.

8. Nakamura H, Saji H, Idiris A, et al: Chromosomal instability detected by fluorescence in situ hybridizationin surgical specimens of non-small cell lung cancer is associated with poor survival. Clin Cancer Res 9: 2294-2299, 2003.

9. Cheng ZQ, Wang XM, Shan J, et al: Detection of p53 gene deletion in primary lung cancer by dual-FISH technique and its clinical significance. Clin Med Chin 26: 368-371, 2010.

10. Uchino S, Saito T, Inomata M, Osawa N, Chikuba K, Etoh K and Kobayashi M: Prognostic significance of the p53 mutation in esophageal cancer. Jpn J Clin Oncol 26: 287-292, 1996.

11. Manoel-Caetano Fda S, Borim AA, Caetano A, Cury PM and Silva AE: Cytogenetic alterations in chagasic achalasia compared to esophageal carcinoma. Cancer Genet Cytogenet 149: 17-22, 2004.

12. Curtis C, Harris MD and Hollstein MC: Clinical implications of the p53 tumor suppessor gene. N Eng J Med 329: 1318-1325, 1993.

13. Smith DR, Ji CY and Coh HS: Prognostic significance of p53 over expression and mutation in colorectal adrecarcinomas. Br J Cancer 74: 216-223, 1996.

14. Fritcher EG, Brankley SM, Kipp, BR, et al: A comparison of conventional cytology, DNA ploidy analysis, and fluorescence in situ hybridization for the detection of dysplasia and adenocarcinoma in patients with Barrett's esophagus. Hum Pathol 39: $1128-1135,2008$. 
15. Kawai T, Hiroi S, Nakanishi K, Sakurai Y and Torikata C: Abnormalities in chromosome 17 and p53 in lung carcinoma cells detected by fluorescence in situ hybridization. Pathol Int 54 413-419, 2004.

16. Varshney D, Zhou YY, Geller SA and Alsabeh R: Determination of HER-2 status and chromosome 17 polysomy in breast carcinomas comparing Hercep Test and PathVysion FISH assay. Am J Clin Pathol 121: 70-77, 2004.

17. Fujiwara T, Cai DW, Georges R, et al: Therapeutic effect of a retroviral wild-type p53 expression vector in an orthotopic lung cancer model. J Natl Cancer Inst 86: 1458-1462, 1994.

18. Lu SM, Cheng CL and Sheng BY: Immunohistochemical detection of p53 protein altered expression in 1364 patients with maligant tumors and its clinicopathological significance. Chin J Cancer 20: 620-623, 2001.
19. Li JD, Li H and Shen ZY: Esophageal spontaneous apoptosis and nuclear value-added antigen, relationship with p53. Chin J Oncol 20: 415-417, 1998

20. Idiris A, Madiniyet N, Hadeti B, Zhang Z, Ilyar S and Wen H: Molecular pathological diagnosis for early esophageal cancer in Kazakh patients. Oncol Lett 13: 549-553, 2012.

21. Abedi-Ardekani B, Kamangar F, Sotoudeh M, et al: Extremely high Tp53 mutation load in esophageal squamous cell carcinoma in Golestan Province, Iran. PLoS One 6: e29488, 2011.

22. King SI, Purdie CA, Bray SE, Quinlan PR, Jordan LB, Thompson AM and Meek DW: Immunohistochemical detection of Polo-like Kinase-1 (PLK1) in primary breast cancer is associated with TP53 mutation and poor clinical outcome. Breast Cancer Res 14: 40, 2012. 